\title{
The Thematic and Narrative Features of Jeet Thayil's Narcopolis
}

\author{
Dr. T.K. Pius \\ Associate Professor of English, St. Aloysius College, Elthuruth PO. Thrissur, Kerala, India- 680611
}

\begin{abstract}
This paper on the thematic and narrative features of Jeet Thayil's "Narcopolis" attempts to grasp the trend of recent English fiction writing in India as the author himself is hailed by the media as the leading light of the new generation Indian novelists, who are willing to take on the less salubrious realities of life in the world's largest democracy. The novel fits into the recent literary wave of "Dark India", a body of literary fiction which seems to have found a niche in the market, writing as it does of the underbelly of Indian society: its slums, poverty, deprivations, depravations, and destitutions. The paper follows the conventional method of introducing the author and his work, situating it in the context of the author's own life and career, and in the larger context of Indian Writing in English. A major portion of the paper showcases the book's technical, thematic and literary traits which ensured its singular achievement in the art of fiction writing. There are a number of brief reviews on the book revealing readers' appreciation and spontaneous reaction to the technical and thematic issues projected in the novel. However, I believe this is the first serious paper of its kind on the novel, which attempts to feature its strengths through textual evidences and analysis. Thayil's book shows a unique advancement in the direction of experimentation with narrative technique that aids an amazingly accurate depiction of reality.
\end{abstract}

Key words: Plot - Characterization - narrative technique - thematic features

\section{Introduction}

Thayil is a poet and musician who has been writing poetry since he was thirteen. Not very far from joining the league of Arundhati Roy, Salman Rushdie and Kiran Desai, Jeet Thayil, an alcoholic and drug addict for nearly two decades, found his antidote in writing with his debut novel Narcopolis. There are comparisons drawn between Narcopolis and its thematic literary precedents like those of the writings of Burroughs, Baudelaire, and Paul Bowles or with other Commonwealth writers like J. M. Coetzee or Margaret Atwood. Some readers might as well be reminded of Thomas de Quincey's Confessions of an English Opium Eater or Irvine Welsh's Trainspotting for its ability to make the audience see the world with its psychedelically distorted but earnest vision. Yet, it is not easy to state categorically that Thayil's Narcopolis, a tale of opium dens and heroin addiction in Mumbai, joins the above select group.

Thayil belongs to the brave new generation of Indian authors who challenge the established norms of writing, and hardly fear controversy when furthering their opinions. He is now being hailed as the leading light of a new generation of Indian novelists, who are willing to take on the less salubrious realities of life in the world's largest democracy. Narcopolis fits into the recent literary wave of "Dark India", a body of literary fiction which seems to have found a niche in the market, writing as it does of the underbelly of Indian society: its slums, poverty, deprivations, depravations, and destitutions. Narcopolis, with its setting on Bombay's Shuklaji Street of the 1970s, and 1980s crowded with opium dens and brothels, with its cast of drug addicts, drug peddlers, prostitutes, criminals, and even a eunuch is a book which definitely sets out to depict a nonshining India, which may be a more faithful representation than what it had been the norm up until recently, of the exotic, lush, extravagant India. While presenting Narcopolis at the Jaipur Literary Fest in 2012, Thayil had this to say about Salman Rushdie's ban in India: "It seems there is a contingent of people at every gathering looking at a sentence or a gesture to get offended. It is cheapening of the idea of rebellion" (Samantara). This is a sentiment that the entire younger generation in India, finds agreeable. This sort of courage and conviction, largely unheard of for many years, is a great sign of changing times in the sub-continent.

\section{Life and Career}

Born in Kerala, Thayil is the son of TJS George - the columnist extraordinaire - who writes hard-hitting articles on politics and society for the New Indian Express. His sister too, is a well-known journalist. Thayil was married to Shakti Bhatt, a revered blogger and editor. Tragically, she passed away in 2007, at a very young age, of a brief illness. She was immensely popular amongst literary circles, and the government has even instituted an award in her honour. Thus it is easy to assume that writing would have come easily to Thayil. In his younger age, Thayil split his time growing up between Hong Kong, Bombay, and New York City.

He received a Masters in Fine Arts from Sarah Lawrence College, New York, and is the recipient of grants and awards from the New York Foundation for the Arts, the Swiss Arts Council, the British Council and the Rockefeller Foundation. He continued this pattern as an adult: spending twelve years working as a journalist 
in Hong Kong, another ten or so years in Bombay, and in 1998 returning to New York to earn his MFA. In 2004, he moved back to India and began writing Narcopolis. Thayil has said he wrote the novel, to create a kind of memorial, to inscribe certain names in stone. As one of the characters in Narcopolis says, it is only by repeating the names of the dead that we honour them. He admits in an interview that his inspiration for the book was Fyodor Dostoyevsky's The Brothers Karamazov and writers of his generation particularly Rushdie's Midnight's Children and Satanic Verses (Mitra) Narcopolis was shortlisted for the 2012 Man Booker Prize. The jury wrote "Poetry is not often a stepping stone to the novel, but we very much admired his perfumed prose from the drug dens and back streets of India's most concentrated conurbation."(Singh) Thayil won the DSC Prize for South Asian Literature 2013 at DSC Jaipur Literature Festival for this novel. Narcopolis was also shortlisted for The Hindu Literary Prize (2013). Though it is his first novel, Thayil is no stranger to the written word. He has published and edited several volumes of poetry, including These Errors Are Correct, English, Apocalypso and Gemini and is the editor of The Bloodaxe Book of Contemporary Indian Poets (2008) and, not to stop there, Thayil is also a songwriter and musician.

\section{Setting of Narcopolis}

Thayil's Narcopolis is set in Bombay, for the most part, but it is not the glorified slum Bombay of Slumdog Millionaire or the Anglo-influenced post-colonial India of Vikram Seth's novels or Satyajit Ray's masterful films. Rather he sets his rich, chaotic, hallucinatory dream of a novel in Bombay, a city made of islands reclaimed by the British, a polyglot culture where all of India's languages, faiths and castes mingle, where the prevailing currency is money and its dreams are told, in those schmaltzy, kitschy Bollywood movies, and which lives on an edge, periodically blown up when terrorists set explosives, but returning to life the next day, resilient and resigned. The ingenuity of Thayil's novel lies in how he has squeezed this entire universe into an opium den in all its compelling squalor in the 1970s and '80s, with a cast of pimps, pushers, poets, gangsters and eunuchs. The Judges making an assessment of the novel said, "Bombay is the first and last word of this first novel, an urban history written by a former drug addict through the changing composition of opiates and the changing characters of their users." (BBC, 11 October 2012)

Thayil paints a stark portrait of Mumbai. The city is frenetic, but in the opium den time moves very slowly. He recollects his deep relationship with Bombay, his addiction and how this book came about: "I went to school there as a boy. I went to St. Xavier's. My family left for Hong Kong when I was eight where my father was working as a journalist. Then I went to school in New York and then came back to Bombay in 1979 and joined Wilson College. In all, I've lived in Bombay for almost 20 years." (Jaiman) When he was asked why it makes him feel strongly about the city, he said: "Bombay does that to people. It makes a (connection) with you. It makes it difficult for you. It bludgeons you. I've been reading about that area, Shuklaji Street. It is disappearing now - Kamatipura, Shuklaji street, (the) entire area between Mumbai Central and Grant Road is disappearing, being bought away by real estate sharks who are buying up all the broken-down houses and making tall buildings. So very soon that entire district will disappear, and with it a million stories. A look of Bombay will go... a certain character will go. Those people who live there now of course won't be able to afford to live there." (Jaiman)

At the end of Narcopolis, the author quite indignant to draw the picture of present Bombay as a very uniform-looking place bearing a high-rise tenement kind of look of uniformity brought about by the political changes wholly supported by the right-wing, and the kind of socio-economic changes widening the rich-poor divide. The face of old Bombay that welcomed people of other communities or for that matter, anybody with talent, ambition, with beauty, with brains was just chipped away. The change from Bombay to Mumbai hints at this change, the change from this old 19th century romantic, glamorous, quiet, slow world of opium to the quick, brutal, modern, degrading world of cheap heroin. Interestingly, there took place a class shift - it is now the poorest, the absolute down-and-out street guys who take to it. Earlier when opium was happening, it was respectable as it was the well off who did it, the upper-class Urdu-speaking elites.

\section{Title}

The title refers to a city of narcotics. As historian Amar Farooqui has shown in Opium City (2006), Bombay's prosperity owed much to that trade. Narcopolis is set at a time when the popularity of opium is waning, and more dangerous drugs are about to invade the city. It makes the opium den look like a piece of innocent nostalgia. The first sentence of the novel begins, "Bombay, which obliterated its own history by changing its name and surgically altering its face, is the hero or 'heroin 'of this story...a great and broken city..." The opening sentence runs on for seven pages and sets the tone of the novel. The novel is about Bombay in the late 70s, 80s and 90s and the author wanted it to be a memorial to a vanished city and to people he knew there. He decided to call it "Narcopolis", because Bombay seemed to him a city of intoxication, where the substances on offer were not only drugs and alcohol, but also god, glamour, power, money and sex. He called Bombay Narcopolis because the city was built on opium shipped to China by the British East India Company working 
with a small group of Parsi ship owners - a secret history omitted by most history books. India's opium links with China are old. Amitav Ghosh's the first two novels in Ibis trilogy, Sea of Poppies (2008) and River of Smoke (2011), trace those links. British traders got China addicted to opium grown in India, and transported it on ships owned by Indian merchants. Thayil in an article in The Guardian, speaks about the subjective and objective reasons for entitling the book this way: " I thought of the people I used to know as Narco Polos, voyagers into the unknown, who seldom returned whole or alive; because I was living on Cemetery Road and it seemed to me I was living in a city of the dead; and because this title suggested another, a hidden title, Necropolis." (Thayil, 12 October 2012) As the title suggests, the book is about drugs and about places. But it's about much more than that as well.

Thayil tells this story through the city's microcosm - an opium den in Suklaji Street, whose existence was known only to those who needed to know: "Shuklaji Street was a fever grid of rooms, boom-boom rooms, family rooms, secret rooms that contracted in the day time and expanded at night" (135). It stretched roughly from Grand Road to Bombay Central and to walk along it was to tour the city's fleshiest parts the log rooms of sex and "nasha". His Narcopolis treads a neater narrative line, but is no less adventurous in its exploration of story and place. This is Old Bombay as seen from the slums and the gutter, the city illuminated in all its sweat and temper, stories lifting from the streets like the smoke from an opium pipe. Centred on Rashid's squalid drug shack, this portmanteau novel picks up strands, weaves them with others, journeys to Mao's China, only to drop us back, mesmerised, right where we began. The story - or network of stories, for the novel is formed of several interconnected narratives, each focused on a different character - revolves around Rashid's opium establishment, which is frequented by gangsters and garad-dealers, pimps, pushers, junkies, tourists. His novel takes the reader through the Mumbai drug world's smoky alleys and features the musings of opium addicts in the late 1980s; it is a journey into a sprawling underworld written in electric and utterly original prose. Thayil has written an episodic, phantasmagorical account of the drug life.

\section{Plot}

There isn't much of a plot in Narcopolis; what Thayil offers is a series of vignettes, at times gritty and raw, at times melodious and soft. Setting his narrative against the backdrop of a changing India seems overarching, and parts of the text feel long and even unnecessary. Yet, Thayil is an accomplished poet and that sensibility serves him well. We slide in and out of characters' lives, emerging occasionally inside a vivid druginduced recollection. The narrator has fallen into trouble in New York City, caught with drugs in his pockets after running from a police officer, shipped to Bombay "to straighten out." It is difficult to imagine a place less conducive to straightening out than the 1970s Bombay of this novel. Episode after episode for year after year for more than 30 years, the drug use and casual sex continue with little evidence of redeeming social value. Appropriately, the use of "heroin" in the opening sentence is not a misspelling of "heroine". Bombay is a drug that sucks people into its seething maw. The city, which is as much the centre of the novel as the narrator, remakes itself in the course of the novel. Called Mumbai since 1995, it is now the commercial and entertainment centre of India. As the novel makes clear, however, efforts to stamp out the lawlessness that it endured when the novel opens in the 1970s have not worked. Opium gave way to heroin and the raw underworld continued on its merry way.

Upon arrival in Bombay, Dom finds himself entranced with the city's underworld, particularly with an opium den attached to a brothel and begins his descent into the squalid world of poverty, prostitutes, and pyali. It is Rashid's opium house on Shuklaji Street in Old Bombay where the air is thick and potent, heavy with intoxicating fumes, sometime in the 1970s. Rashid's is the axle around which Narcopolis revolves, the lens through which Thayil considers the city. The narrator quickly becomes a regular at Rashid's opium den, -in the immortal words of F. Scott Fitzgerald, "First you take a drink, then the drink takes a drink, then the drink takes you" - a place where it is possible to lie still and dream for hours or talk quietly with his fellow addicts. There is certain elegance in the preparation of the pipes, the ceremony of it, and Rashid's seems for a while to be the ideal place to disappear. "After a while of this," the narrator says, speaking at a much later point in the book of splashing after someone half-glimpsed on the street during a monsoon, "I lost track of time, I lost myself, which is the reason people like me get into drugs in the first place."

A voluptuous young woman with her hair falling across her dark eyes holds a long- stemmed pipe over a flame, offering it to the men sprawled around her and mutter in the gloom, each one drifting with one's own tide. Here, people say that you introduce only your worst enemy to opium. The seduction of opium beckons even the most stalwart of men. In this world, stray dogs lope in packs and street vendors hustle. Prostitutes call out to their quarry as their pimps slouch in doorways in the half-light, eager to collect their due. This dark and pitiful world is threatened by an underworld whisper of a new terror, a stone killer known as Pathar Maar. This killer is after the nameless and invisible poor, an infinitely large tribe in this dark and shattered city. In a broad sweep, this novel covers the lives of people living in the Bombay of the 1970s. It is an odyssey into a large 
underworld of unimaginable depth where we meet a cast of unforgettably degenerate and magnetic characters who work and patronize the venue.

The novel is broken up into four "books." Book One, "The City of O," begins with Dom's arrival in Bombay. It is the late 1970s, and he quickly weaves himself into the fabric of Bombay's sordid underbelly, specifically, the opium dens. Here he meets Rashid, owner of a khana on Shuklaji Street where much of the novel takes place (and where Dom smokes his first pipe); Dimple, the beautiful hijra who works for Rashid preparing bowls of opium; "Bengali," who manages Rashid's money; Rumi, the unflinchingly confrontational businessman whose addiction is violence; Newton Xavier, the celebrated painter who both rejects and craves adulation; Mr. Lee, the Chinese refugee and businessman; and a cast of poets, prostitutes, pimps, and gangsters. Here, people say that you introduce only your worst enemy to opium. The seduction of opium beckons even the most stalwart of men. In this world, stray dogs lope in packs and street vendors hustle. Prostitutes call out to their quarry as their pimps slouch in doorways in the half-light, eager to collect their due.

The readers are introduced to the novel's key character Dimple who worked at Rashid's opium den during the day time and disappeared in the evening to the hijra's brothel. We are introduced to her understanding of love and relationships between men and women. Comparing men and women, she says, "Women are more evolved biologically and emotionally... But they confuse sex and the spirit; they don't separate. Men ... always separate: they separate their human and dog natures" (12). She has even drawn family resemblances between men and dogs.

Dom's introduction to Rumi is made to sound very casual. He overheard a conversation between a pimp and a tall man. After the pimp left him, he turned to Dom and said," pimps are cowards... pimps make their money from the weak and the diseased, from men and women whose will has deserted them, who will never fight or put up any kind of resistance, who want to die ... You've got to face facts and the fact is life is a joke, a fucking bad joke..." (22)

Dom also gets introduced to a famous painter, Newton Xavier who was to make an appearance in the city to read poems. There are echoes of Roberto Bolaño in the book's early pages, especially a memorable scene where the narrator attends a talk given by the extravagantly drunk painter Newton Xavier and ends up escorting him back to Rashid's. Most writers agreed that Newton Xavier was "enfant terrible and brilliant; a postmodern subversive ..., a drunk whose epic binges were likened to those of illustrious alcoholic predecessors such as Dylan Thomas, Verlaine and J. Swaminathan ...; a wild child now in early middle age who outdid the Romantics' antics..." (25) He was art-obsessed, self-absorbed, precocious poet who explored chaotic themes like, 'the world as a manifestation of the estranged mind'. His audience hoped to see him combust in front of their eyes, or implode, or die of a heart attack or leap from his seat and rape an audience member". (30). Xavier's pithy statements like, "only the rich can afford surprise and/irony" (39)," An addict... is like a saint" (40) are sufficient nourishment for those inclined to think philosophically. Soon readers realise Newton Xavier is the hand-off; he arrives in the story from the perspective of the narrator, and then goes off alone with someone else as the story shifts into the third person and Thayil begins to follow the stories of the other denizens of Rashid's.

In fact, Dom has several run-ins with Newton Xavier Francis, before disappearing near the middle of Book One and not returning until well into the second half of Book Three. Once he vanishes, he is replaced by a third-person omniscience that suddenly steps in to tell us the inner workings of other characters' minds and their personal histories. This narration has the ring of the truth, or at least what the characters themselves see as the truth. Dom's absence turns in the other "I," of the Prologue. It is through the mouth of an ancient opium pipe that we hear these stories. The ambiguous "Pipe" takes us to Dimple's perspective. We witness her encounters with Xavier and follow her into her dreams. The narration swoops back in time to when a much younger Dimple is experiencing body pain as a result of hormonal changes from being gelded at a young age. She visits a Chinese man called Mr. Lee, who provides her opium to ease her pain.

Book Two, "The Story of the Pipe," (73) centres on Mr. Lee, a former soldier who fled communist China and now, a Chinese drug dealer. He had a minor stroke and after being hospitalised for a few days, he came home with lot of fear in his eyes. "His mind skipped years, slipping backward or forward without regard for chronology. He lost faith in linear time". (76) He told Dimple his autography describing the places he lived in like Rangoon, Chittagong, Delhi and Bombay. His voice rarely rose above whisper and the readers witness his childhood and youth, his falling in love with Pang Mai, his time in the army, and his subsequent exile and flight to India and, eventually, Bombay, which he hates but stays in because he is drawn to the sea.

A couple of chapters in this section speak about Lee's village and his parents. The village of lees was known not only for the ideological correctness of its inhabitants but also for his father, who wrote a series of novels about a tramp named Ah Chu. Lee's mother did not believe in knowledge that did not benefit society as a whole. She said that some kinds of knowledge were not meant to be freely available, because all men and women are not equipped to receive such knowledge in an equal and equally useful way. Lee's father being a popular writer was summoned to the communist headquarters along with other prominent writers to attend a 
series of talk by Mao Tse-tung. In the session titled "Talks on Art and Literature" Mao laid down a number of guidelines for writers. He was quite unhappy and silent about what had occurred there. When he published the last of the Ah Chu stories named The Eruption of $\mathrm{Ah} \mathrm{Chu,} \mathrm{it} \mathrm{brought} \mathrm{some} \mathrm{unwelcome} \mathrm{official} \mathrm{attention.} \mathrm{This}$ was followed by a thin volume titled Prophecy. It was 1957, the year of the first purge. When the book sellers realised the nature of the book's contents, they destroyed their copies. The official's verdict was quoted in the People's Daily: "What can a decadent daydreamer and bourgeoisie do? We will not let you pollute the socialist future of China!" (91) Lee's father's career came to an end with this but before he could be taken to prison, he fell ill. A few days later, Lee's father died of fever and malnutrition. Lee discovers a copy of his father's last book and on reading it he understood that it had been his father's true life's work.

Mr. Lee's sharp portrait of the horrors of a communist regime in the late 1940s does highlight his unusual friendship with Dimple, in whom he confides the story of his lost life and loves. In a conversation with Lee, Wei sums up the political uncertainty of the time. "If I am under attack, you are next. There are few things you can be certain of at this time: blood lust; group attacks against those who are alone or isolated; packs of dogs running wild through the streets; the end. This is our reality. Anything can happen to anyone at any time". (117) Lee fled from Peeking and reached India; lived in many cities and towns that he never learned the names of. Before he dies, Mr. Lee asks Dimple to bury him in China. He also leaves his family's magnificent old opium pipes, which she barters for a position at Rashid's khana, where she will make pyalis all day in exchange for opium of her own to smoke. The opium pipes bring widespread fame to the den-so much fame that that people from all over the world and all walks of life pass through it. Hippies arrive and begin to appreciate the quality of Rashid's opium, the attention to detail in pipe preparation, the warm cocooning charm of it all. Rashid's competitors are hell bent on destroying it. In that den, Rashid and Dimple build a rock-solid friendship through the years.

Book Three, "The Intoxicated," (132) has twelve chapters with the initial ones describing Rashid thriving in his business but losing his peace of mind, Jamal his son who without much effort takes after him, Salim, from whom Rashid buys bottles of Johnnie Walker and the new garad heroin, Lala, Salim's employer and old gangster who likes quoting from the Baburnama: "Women for procreation, boys for pleasure, melons for delight"(139). There is also a chapter on Bengali who had served Rashid in his shop since early days. The remaining chapters enlighten the reader on the intimate relationship between Rashid and Dimple, the transformation of Shuklaji Street and its impact on the major characters and also Dimple's and Rumi's life at Safer, the rehab centre.

Khalid, one of the opium businessmen of Shuklaji Street had reasons to be jealous of Rashid's Khana, which had become local landmark. Khalid's Khana, situated just next door to Rashid's had only a small room, with a single pipe and no customers. Khalid thinks of trying his luck with the new popular drug to give a new lease to his business. The following conversation between Khalid and Rashid reveals the latter's unwillingness to join in the new business of garad heroin. "A chanduli can smoke for years and be healthy; garadulis are impatient, they want to die quickly. You say we're businessmen and we should provide what people want. What kind of businessman would I be if I supplied heroin to chandu customers? I would be a chooth businessman. I'd be shooting myself in the foot. Why I'm telling you this, it's my way of saying don't ask me again to join you in business" (154) Salim would explain a few pages later to Dimple the source and nature of garad heroin: "Garad comes from Pakistan. Garad, you know what it means in Urdu? Waste. This is the unrefined shit they throw away when they make good quality maal for junkies in rich countries". (199) Often there are shortage of vegetables in the market but not garad chemical. The city is run by politicians and they know only too well that there is a multi-crore business in the sale this Chemical. In Bombay money is the only religion. At the end of this brief but intimate conversation with Salim, dimple said, "The world is ending... anything can happen to anyone at any time" (199)

Dimple observed that when the city was burning and everywhere was rubble and smoke and smouldering taxicabs and trucks, the police station remained closed. "The police and the dogs, it seemed to her, were always the first to smell trouble and disappear" (200) There was nothing to be afraid of because nothing really mattered. In the street she found men staring at her quite different from the usual: "it was more businesslike, as if they were weighing her for meat, guessing how much she would fetch in the market"(200). She sought refuge in a church and for some moments she pondered on the figure of crucified Christ. "His wounds were dramatic and glossy, movie-star wounds that would not heal, that would stay forever raw and the circle of thorns on his head dripped blood into his eyes and colourful lips.(201) The figure seemed to tell her "Love me because I'm poor and alone like you" (201).

This section of the book depicts the tumultuous crumble of the mostly mellow opium dens into the brutally effacing world of chemical heroin. There was something almost ritualistic in those traditional opium dens, the least the way Rashid perceived them: "It was just short of noon and already the khana was dark, in a kind of permanent half-shade. The room made people talk in whispers as if they were a place of worship ... Already now there were times he could feel it slipping away, a way of life vanishing as he watched, the pipes, 
the oil lamps layered with years of black residue, the conversation that a man would begin and lose interest in, all the rituals that he revered and obeyed, all of it disappearing." (148) Bombay becomes Mumbai and for Rashid and Dimple that change arrives in the form of heroin from Pakistan.

It is a drug that seems to herald a new world order, one more savage and hopeless than anything that went before. The new chemical would remove all possibility of pain: "If pain is the thing shared by all living creatures, then I'm no longer human or animal or vegetal; I am unplugged from the tick of metabolism; I am mineral".(219) All the regulars switch not knowing " for every happiness there is an equal and opposite unhappiness" (220). The city's underbelly becomes rawer than before. Those in their circle still use sex for their primary release and recreation, but the violence of the city on the nod and its purveyors have moved from the fringes to the centre of their lives.

When Dimple smoked the chemical for the first time she had many nightmares, starting with the house of blue pools and ending with her last conversation with Mr. Lee. When Rashid heard about it, he was impatient to try it. Soon he was dreaming Dimple's dream. For "Dreams leak from head to head; they travel between those who face in the same direction, that is to say lovers, and those who share the bonds of intoxication and death." (187). Years later, after the death of Dimple, when he was old and pious and waiting for her ghost, he was still dreaming her dream. He heard her future words, with which she would greet him: "dreams leak and the dead return, but only if you love us" (188). Towards the end of the section which fills Rumi's ruminations, has a rereading of Dimple's 'dreams':"with dreams came memories, or perhaps they weren't memories at all but fantasies she imagined were memories" (239)

Rashid's khana is shut down, reopened, and shut down again. "There used to be thirty-six chandu khana on Shuklaji Street ... now mine is the last one, perhaps the last one in the whole city... you'll think it's the last chandu khana on earth. And that too will be gone" (217) But there is something more that will also disappear with it. "The words we said and the people we knew, and you and me, all of us will be sucked away like smoke in the wind"(217-8) and in its place there would be new business enterprises.

Dimple leaves the brothel she has worked at nearly her whole life to live at Rashid's, on the half landing between the khana and the upstairs floor where his wives and children live. Dimple decides to leave the brothel in order to make her own future. Her move to Rashid's could be a positive one but is derailed by the new drug of choice in town. Not to mention that she is expected to act as Rashid's sex partner whenever he is in the mood." To mark her new situation, he gave her a new name, Zeenat, and he brought her a burkha" (156) She was named after Zeenat Aman, the bronze-skinned mini-skirted actress of Rashid's favourite movie Hare Krishna, Hare Ram. Besides, Zeenie in the movie was playing a woman who runs away from a broken home and renames herself Janice. Standing before the mirror wearing burkha she whispered to herself "Zeenat" and she felt "this was something very differrent. Only the face was visible, only the feet and hands, and because everything was covered, a glimpse of eye or mouth became tremendous and powerful".(157)

When she went out in this dress, she perceived the way men looked at the lipstick on her mouth and the kaajal around her eyes. However, she did not give up saris. "She varied her costume depending on who she wanted to be, Dimple or Zeenat, Hindu or Muslim. Each name had its own set of adornments".(158) She changed out of the sari and put on a salvar when she was with her customers. Bengali noted that her relationship to Rashid also got drastically changed. He was dismayed by her manner around his boss: "look at this woman, until yesterday she was a prostitute in a hijra's brothel and listen to her now, talking as if she's Rashid's equal... she talks as if she is his wife and Rashid listens like a husband" (176) Bengali was not off the point in his observation. She is "more than a wife, more than both his wives put together: she's his business partner and she's better at it than he is."(176)

Soon the "I" narrator, Dom, makes a brief return to the narrative. He deposits Dimple in the rehab centre, named Safer where he himself had the most unsuccessful cure: it was the last-ditch effort to save her and then he leaves. In the mean time, the other characters that flit in and out of this story disappear or die. Dimple too dies. Still, Rashid cannot forget Dimple. Dimple, he tells Dom Ullis, haunts him every day. She is always there, always will be. The section ends with Rumi's days in the rehab with Soporo and Bull.

Book Four, "Some Uses of Reincarnation," (263) returns narrator Dom to Bombay. It is 2004 (the year also of Thayil's return). Those he knew are almost all gone, but the passion he feels for them and for the city is revealed. He arrives at Shuklaji Street to find the area disorientingly different. The former red light district has transformed into stores, businesses, and fast food restaurants, and Rashid's khana is now an office space, run by his son Jamal. Dom speaks with the aged Rashid to find out what happened to his friends."Rashid sat in an armchair by an open window and ... stared out the window but there was no sign that he saw or heard anything. There was a crocheted white skullcap on his head and he was counting prayer beads". (277) Dom was surprised by his thinness, "the expression of unreachability on his face"(277) and noted that his charisma was gone. He gathers from him that Dimple, Bengali and Rumi are all dead. Rashid left the room only occasionally, sometimes for a walk, sometime to the apartment on the half landing where his kamavali used to live and no one 
knew what he did there. Rashid and his son rarely spoke because conversation was Jamal's weapon, a way to antagonise his father

We catch a glimpse of the newer generation when we follow Jamal and his fiancé, Farheen, to a club. She reminded him of his father's kamavali. "Cocaine, and MDMA and Ecstasy" are the new flavours of the hour, "new drugs for the new Bombay" (281) and Jamal follows in his father's footsteps, as a cocaine salesman. Shiny surfaces abound - in the club and, more and more, in the city — but what's below them is doubtless no less raw and depraved. It will always go on; the story doesn't end. "Dance or we die," (284) says Farheen to Jamal.

Dom goes through the belongings Dimple left at Rashid's. Among them, he finds the opium pipe. Rashid told him to take whatever he wanted since Jamal intended to throw them all away. Dom said he might make a museum out of the things he found in the trunk. Rashid said, "Put our shame on display, so the people understand the lowest of the low, prostitutes and criminals and drug addicts, people with no faith in God or man, no faith in anything except the truth of theirs". (288) The book ends in the same spot it started: Dom and the pipe and the account they've now made together, a metatextual call out signalling the circularity. Thayil completes the story that began in the 19th century through Lee's pipe, as it becomes the instrument of escape for the city's tormented souls.

\section{Characterisation}

The city, the Narcopolis, is the central character around which all the human characters swarm. When the narrative dissipates into smoke, it leaves a deceptively addictive odour, with fascinating cast of flawed but memorable characters at the margins of society. His characters, he wrote in an author's note, "were the marginalized, the poor, the degraded, and the crushed, whose voices were unheard or forgotten, but whose lives were as deserving of honour as anyone else's." He never looks down on his characters.

There is Dimple, the eunuch who is keen to read and learn and who makes pipes in the opium den and dreams of a better life; the Bengali who pretends to know more than he does (or maybe he does); Rumi, a husband addicted to violence; Mr. Lee, a Chinese refugee who managed to drive a stolen vehicle out of China and into Bombay; the unobtrusive narrator Dom, whose soul-killing job is as a proof-reader of publicity material in a pharmaceutical company (with easy access to chemical substances) and Rashid himself, who runs the opium den with disdain that is at once sardonic and laconic. There are the others too, given peculiar names drawn from Bombay slang, but most try to do no harm, and often show heart-warming humanity: a vast supporting cast of pimps, prostitutes, and criminals who drop in and out as the situation demands. The variety of characters enabled Thayil to honour the people he knew in the opium dens, the marginalised, and the addicted and deranged people, who are routinely called the lowest of the low. His concern was for the history of the marginalised whose world no longer exists, except within the pages of a book.

\section{VI.1. Rashid}

Initially Rashid was a skinny criminal trying to make a name and then he turns out to be a fat businessman, an entrepreneur, "with cash in his pocket and the shortest commute in the world" (135). At the end of it all he would admit "none of it gives me a moment of peace in my head" (135). Years of his work in khana had almost disfigured him and he often "looked away from his degraded image" (146) in the mirror. Rashid's opium room became a landmark with trained staff, the best quality $\mathrm{O}$ and genuine Chinese opium pipes. The opium tourists, who had heard about the khana, possibly from a friend on a beach somewhere in Spain, or a café in Rome, would come all the way to Shuklaji Street to see for themselves.

Rashid would rush to the khana soon after he got up from bed because his system stunned from six or seven hours without drugs," his head reeling with visions of hellfire and the annihilation of godless world" (136). When he was opium sick and sober, he felt God was always close. And then he whispered, "Guide thou us on the straight path, thou who are round about the infidels. Thy lightening snatches their eyes." (137) Rashid had been a believer for most of his life, meticulously observing the five prayer times followed by the dietary strictures. Yet his habits had never been stagnantly constant rather quite negatively dynamic exchanging one habit for another: "he had given up God and accepted O" (142) and now embraced garad heroin.

When he was nearing the end of his life, he would sit in an armchair by an open window with a crocheted white skullcap on his head counting prayer beads. His charisma had totally disappeared and there was an air of inapproachability about his face. Rashid left the room only occasionally, sometimes for a walk, sometime to the apartment on the half landing where his kamavali used to live but no one knew why he went and what he did there.

\section{VI.2. Dimple}

If there is one character that embodies the heart and soul of the book, it is Dimple. The most captivating of the city's denizens, Dimple is neither man nor woman, a hijra, (a eunuch) technically a man but referred to throughout with female pronouns and wears woman's clothing. Her mother gave her to a priest when 
she was still a boy, and the priest sold her to a brothel. She works at the opium den part-time, at first; evenings are given over to the brothel. She is on an endless search for knowledge and beauty. She has taught herself to speak English, and is teaching herself to read. When she takes over the story, the shift is so gentle that it takes some time for the reader to realize that the narrator has faded into the background and hasn't been seen in some time.

Dimple says of herself: "woman and man are words other people use, not me. I'm not sure what I'm. Some days I'm neither, or I'm nothing. On other days I feel I'm both.”(11) The neither/either/both that defines Dimple's gender applies to so much in the book and so much of what the book is doing. The idea of syzygy, which Bengali introduces, is especially salient here: it's a concept that can refer to both "a conjunction and opposition" and a "pair of connected or corresponding things." (20) Someone read out a quote from the Mahabharata which appeared in the editorial page of the newspaper which said, "Only eunuchs worship fate". And then to make a joke of it the man asked Dimple if it was true. The words stayed with her. She believed in Fate and Ghosts and bad luck: "if this made her doubly a eunuch there was nothing she could do to change it. It was fate."(76)

Like Tiresias of Greek mythology, Dimple has known both worlds: "I'm both and I've learned some things, to my cost, the kind of thing you're better off not knowing if you mean to live in the world" (11). She claims that she has certain insight on love concealed to most others. She has an understanding of how lovers want to consume and be consumed, and disappear into each other. She says, "I know how they yearn to make two equal one and I know it can never be" (11). Yet from her own experience she asserts confidently that "Genuine union is impossible; all we can hope for is cohabitation" (18).

Thayil testifies "She was the one who made pipes in an opium den in about 1980-81. I only saw her twice. Then she disappeared. Many people in that world disappear. There was something about the way she used to make the pipe, very elegant." She is a prostitute and like all the main characters in the novel, a drug addict; opium is the only thing that lessens her pain. Dimple is the moral and emotional centre of the novel; despite her terrible experiences she has a sweetness, gentleness, tolerance and lovability which go far beyond the usual "tart-with-a-heart" cliché. Dom the narrator reports how he was often transported to a trance-like dream induced by Dimple's opium pipe. Dimple liked Dom who asked her many questions. She understood there was only a thin veil that separated one from ones dreams: "On the other side of the mirror, our hands are resting against the glass, trying to touch your face. Only a veil separates us from you, a transparent veil as flimsy as the one that separates you from your dreams." (20)

Dimple painfully narrates how she was forced to go through the process of gelding and docking when she was just nine or eight. She was brought to Bombay to a hijra's brothel."A woman was called, a famous daima, Shantibai. There was singing and dancing and whisky. The daima told me to chant the goddess's name and she gave me a red sari. She made me drink whisky. I hated the taste but I drank it. They gave me opium. Then four of them held me down. They used a piece of split bamboo on my penis and testicles and held me down. The bamboo was so tight I felt nothing, until afterwards, when they poured hot oil on my wound. That was when I felt the pain ..." (66-67)

Dimple hardly remembers her mother but she considers it a blessing to forget her childhood past: "My mother gave me to a priest, who brought me here to 007 and sold me to the tai. I was seven or eight. I don't remember much about my mother or my life before I came. I don't want to remember.

Best. Forget is best.

Why remember and make yourself sad?

Why remember when you memory wrong, ALL WRONG

Yes, yes, best to forget (67)

When Dimple's income dropped owing to her ill health, Tai took her to Mr. Lee. She was dressed like a good Indian girl going to meet her elders. Dom, at this point, tries to read what goes on in Dimple's mind: "Clothes are costumes or disguises. The image has nothing to do with the truth. And what is truth? Whatever you want it to be. Men are women and women are men. Everybody is everything. She thought: Who do I look like? Do I look like my mother? ... She had no idea and for that she was grateful. Forgetfulness was a gift, a talent to be nurtured". (57) Lee gave her a pallet to be swallowed with milk. In about fifteen minutes the pain left her, to be replaced by its opposite, "something that enveloping that told her she was loved, no, beloved: she was beloved and not alone". (60

She learned English by conversing with customers and by reading whatever she could get hold of. Vacillating between prescience and naiveté, Dimple was driven to communicate; she then was a "story addict" obsessed with language, who would read anything she could, though while she was still becoming literate, she didn't really get genre. She believed "Sex Detective" is a true-crime narration. "It's not a book," a humoured Dom tells her. "And this is not a pipe."

Khalid one of Rashid's business-mate was once politely reprimanding Rashid for allowing Dimple to talk too much: "Your kaamvali, the hijda Dimple, why do you let her talk so much? ... Our scripture says 
women must be silent in the assemblies of men". But Rashid knew that his customers liked to hear her talk. Khalid was quite aware of the double meaning in the word "kaamavali", for "kaam" is work in Hindi but desire or lust in Sanskrit.

Jamal behaved as if Dimple was his enemy until the day she saved him from a group of men who had grabbed him by his kurtha and were shouting at him. From then on he always greeted her. To Dimple, this was "a great thing, an achievement, something, finally, to be proud of" (205)

Like Bombay's, Dimple's name does not remain fixed. She was originally (re)named after the beautiful Dimple Kapadia, of the film Bobby. She was then renamed, after a film star - this time Zeenat Aman-by Rashid, who took her to a movie "Hare Rama Hare Krishna", in which "Zeenie" plays a character who has renamed herself Janice and run away from home. Again, we have this undercurrent of exile and separation. In fact, the word hijra is etymologically related to the Arabic hjr, which refers to leaving one's tribe.

Rashid gave Dimple a new name and a new identity when he asked her to begin wearing a burka. For a while she enjoyed slipping between her two identities. Dimple had always found some power in deciding what to wear-be it burka, sari, or "trousers because it allowed her ... to act like a man when she wanted to." She recognized that "clothes are costumes, or disguises. The image has nothing to do with the truth. And what is truth? Whatever you want it to be. Men are women and women are men. Everybody is everything."Dimple moved between religions, genders, states of reality, time, clothes, names, roles. She dreamed she was rich; she identified with Jesus because he too was poor. She learnt to use new languages: teaching herself English, learning to swear in Cantonese from Mr. Lee and so on.

Dimple also acknowledged - and had been unequivocally abused by - a gender disparity that placed men squarely on top : "For conversation, better to be a woman, for everything else, for sex, better to be a man." The misogyny on display in Narcopolis is enough to make any non-misogynist cringe, even though it is clearly intended to be satirical or subversive in most cases. But there are no strong female characters, excepting Dimple, who though in many ways female, is biologically male and doesn't see herself as solely a woman.

\section{VI.3. Jamal}

Rashid's older son Jamal was already a businessman when he was six years old. "The boy had a way of appearing without making a sound, materialising from nowhere with his eyes wide and his hand extended" (135) to get some cash from Rashid. Rashid was once shocked to find his son smoking and he shouted "Six years old and you are on the street, fucking and smoking" (143). Jamal followed in his father's footsteps, as a salesman of the new flavours new drugs "Cocaine, and MDMA and Ecstasy". When he becomes older, we see a glimpse of the newer generation as Jamal and his fiancé, Farheen, spend lot of time in a club. At the end of the novel, we find Jamal and his father rarely spoke to each other because conversation was Jamal's weapon and he frequently used it as a means to antagonise his father.

\section{VI.4. Bengali}

Bengali was aged between fifty and seventy, gaunt, wrinkled and spoke English with an affected British accent. He kept Rashid's accounts and looked after the shop. He had been with Rashid since the early days "when Rashid was a tapori selling charas near Grand Road Station" (145). He spent most of his time locking and unlocking a tin box that served as a register, putting in money and paying out. No one knew anything about his life before he came to Shuklaji Street except that he had been a clerk in a government office in Calcutta. He talked about mythological, religious and political figures as if he knew them well. The Narrator says, " He shared the regional affliction that Bengalis were prone to, the conviction that they were the most aristocratic and talented people in the world" (147)

\section{VI.5. Lee}

The elderly Mr. Lee, a refugee whose upbringing in Maoist China is described in some of the book's most harrowing chapters. Lee is a former soldier who fled from communist China, anticipating the possible threat to his life after his father published a thin volume titled Prophecy. It was 1957, the year of the first purge. When the book sellers realised the nature of the book's contents, they destroyed their copies. The official's verdict was quoted in the People's Daily: "What can a decadent daydreamer and bourgeoisie do? We will not let you pollute the socialist future of China!" (91) The communists considered him a decadent daydreamer who would pollute the socialist future of China. Lee's father's career came to an end with this but before he could be taken to prison, he fell ill. A few days later, Lee's father died of fever and malnutrition. Lee discovers a copy of his father's last book and on reading it he understood that it had been his father's true life's work.

Lee in the novel is a Chinese drug dealer who gives Dimple her first hit of opium as an antidote for her back pain. Mr. Lee's sharp a portrait of the horrors of a communist regime in the late 1940s do highlight his unusual friendship with Dimple, in whom he confides the story of his lost life and loves. Before he dies, Mr. Lee asks Dimple to bury him in China. She never succeeds in getting the ashes there and always reproaches herself 
for being unable to honour her friend's wish. Mr. Lee bequeaths Dimple his opium pipes-Chinese, the real deal - eventually taking her to an opium den run by a character called Rashid.

\section{VII.1. Multiple Narrations}

\section{Narrative Technique}

The book is that structural oddity, a first-person narration with a (mostly) absent narrator, a story that switches quickly to the third person and stays there for most of the duration. This is because Thayil presents the reader in an interesting authorial device, not only with a single omniscient narrator to guide the uninitiated through the potholed journey on Shuklaji street, but with a cast of narrators, each taking over the telling of the story so seamlessly that sometimes it is unclear whether one narrator has left off and another has picked up. There is, very occasionally, the voice of the omniscient narrator towards the end of the book, but for most part, the narrative voice switches from character to character and it is not always clear who the first person narrator is. The multiple narrators, the slippage from one voice to another, the very long sentences and monologues are reading experiences which disorientate the reader, as does non-linear timeline which moves in leaps and jerks, perhaps intentionally giving the reader the simulated experience of being in an opium drug haze, where time, and even facts, are somewhat fluid and uncertain. This mental state is induced from the start of the book where the opening sentence runs for seven pages.

None of Thayil's characters are particularly reputable, and some critics have called them "uninviting" and certainly, although they tell coherent stories, and are consistent within themselves, it is impossible to ascertain if their accounts are accurate or drug induced confessions and fantasies. Their less than respectable, fairly unorthodox, alternative, marginal life-styles, their drug-abusing habits and addictions, their rants, their desperation, all combine to render the characters' seemingly unreliable narrations. On the other hand, there is also a case to be made for the reliability of these narrators despite their lacking conventional credit or social capital: the narrators often demonstrate high degree of self awareness, awareness of the world, and often present what appear to be bleak, uncompromising versions of realities, which come across as convincing and reliable because there is no attempt to euphemise whether this is basis enough on which to trust such narrators to lead the reader through the landscape of menace and drug abuse, disregard for and devaluation of human rights, dignities, and life, is a question each reader needs to decide individually. However reliable, or otherwise, collectively, these narrators patch together a riveting portrait of the seedier side of Bombay.

The novel has a very unreliable quasi-narrator in Dom Ullis, whose return to 1970s Bombay from New York, and his immediate descent into an opiate languor, opens the novel. The readers rarely hear the narrator's name. Dom is absent for much of the book, and what we know about his personal history doesn't extend far beyond snippets. Dom, like the author, is from Kerala, but spends his time in New York, working in an editorial capacity as a proof-reader for a pharmaceutical company, and comes and goes from Bombay and the readers can easily guess his drug habit. Thayil and Dom could both be regarded as providing a certain "staged marginality" which denotes "the process by which marginalised individuals or social groups are moved to dramatise their subordinate status for the benefit of a majority or mainstream audience" (Huggan 2001).

That our narrator is atypical and largely undefined says a lot about the way the book works. As it turns out, narrator Dom is only one of our narrators, only the vessel, most of the time, for our other narrator, an omniscient voice spanning the length of history and breadth of the globe. To whom does this all-seeing eye belong? It is actually all explained in the prologue, though one may need to spend a spell deciphering it, given that the prologue, though over six pages long, is one continuous sentence: clauses, details, explanations, voices strung together in a way that shows chronology and clear-cut narration are not the goal here. Speaking about his choice of long sentences in the narrative, Thayil said:"The opening sentence, the prologue, I wrote that about halfway through the writing of the book, and when I wrote that sentence, I realized this is the way the book should be. And I rewrote the book, changing the language of it with long sentences ... rather than short sentences because I realized the only way to write about opium was to write long, open-ended sentences where the writer who is writing it has no idea where the sentence is going to go. So you follow it and there is a sense of discovery - for the reader as well, I hope. You couldn't write a book about opium, which is a very slow, long process, with short quick Hemingway, journalistic, telegraphic sentences. So once I kind of stumbled on that, it changed everything. Then the book happened very fast." (Jaiman) Having set the stage for the twisting narrative that follows, Dom abandons his reader for the drug. Dom resurfaces periodically, although he is almost entirely absent from the whole middle of the novel.

Thus, this rambling introduction provides us with a glimpse of what's to come in terms of narrative structure, and in terms of the tumultuous, ever-changing but never-resting Bombay the book is set in. The prologue introduces us our unconventional narrators, and it tells us quite straightforwardly not to expect linearity. Dom warns us that "the I you're imagining at this moment... who's arranging time in a logical chronological sequence, someone with an overall plan, an engineer-god in the machine ... isn't the I who's telling this story." (Narcopolis, 1) He further clarifies: "That's the I who's being told," which, though perhaps 
not immediately transparent, is actually the key to understanding the book's somewhat unusual style of narration. It's not tidy, but neither is what it is apparently about, addiction or Bombay. It is Dom whose voice we hear in that seven-page first sentence, in which he introduces us to the idea that there are more narrators to a given story, the I and the other I.

Dom is a very appealing narrator whether reliable or otherwise; unlike many caught up in the snares of the underworld, he has not lost his humanity and still attempts to understand and treat others with respect. In a city teeming with danger, violence, addiction, sensations, and most casual of brutality and commonplace cruelties, perhaps finding in Dom a narrator who attempts to hold onto his principles and basic decency may well be reason enough to trust him. Thus, Dom is not a reliable narrator, although it is hard to tell, sometimes, when he is narrating and when he is not. He is rarely present, and when he is there, he is a mess. Within the novel itself Thayil discusses the use of reliability of the various narrative voices, demonstrating his awareness of unreliability of narrators, but making the case that reliability was not necessarily something to be aspired to: "I told Dimple that the Professor, if that what he was, seemed to be unreliable source, though he was entertaining enough. I said there was nothing wrong with being unreliable. Who wasn't? what in any case was the point of being reliable, like a dog or an automobile or armchair? I said it was fine with me as long as he didn't call himself a historian or moral scientist. (15) But the question of truth, and of reliability, is one that bleeds through the whole novel, setting up one of its many binary challenges. We are asked to consider "hero" as the opposite of "heroine" as well as "heroin" on the first page, but heroin is also opposed by opium; Hindu by Muslim; clean by dirty but also by addicted; rich by poor; real by not real; I by not I. And in Dimple, Thayil asks one of his largest questions - who is a man, and who is a woman, and how do we know?

In the last sentence of the novel, the narrator disclaims responsibility for reliability disingenuously claiming that "this is the story the pipe told me. All I did was to write it down, one word after the other, beginning and ending with the same one, Bombay (292). As always, things are never quite clear or certain in the novel: which pipe does he refer to? Is it a real pipe, a literal pipe, perhaps a pipe inherited from Lee, given to Dimple, then to Rashid and finally to Dom? Or is the pipe merely a metaphor, standing for drugs in general, or standing for stories of the people through whose hands it has passed? How reliable a narrator is a pipe? In passing responsibility onto the inanimate pipe, Thayil shifts the burden of realism and authenticity, and in parallel Dom Ullis, shifts responsibility for the story's outcome by claiming that he in turn was guided. Of course, story-telling is neither transparent nor a translation of life, merely to be written down one word after another - this is wholly disingenuous and conceals the hand of the craftsman and the design, selection and manipulation processes of writing a novel. As Tabish Khair (2001: 4) points out, "Fiction is not same as fact and a novel is not sociology or history or anthropology. And yet there is an intricate relationship between fact and fiction, between sociology, history, anthropology and creative writing". Nevertheless, the attempt to deny that relationship and disclaim responsibility is an interesting one. Thayil chooses seduction over prescription as the method of convincing instead of claiming authority, the narrator leads the reader into unfamiliar lands thus disconcertingly turns shrugs and claims to know no better than the reader.

Narcopolis contains stories, narratives colliding and being passed on almost arbitrarily, changed, lost. It would seem that Thayil is implying this is the only possible way to render an accurate account - by undermining traditionally accepted markers of reliability and accuracy. As U.P. Mukherjee (2010: 128) explained "learning to see oneself with other eyes, eyes that belong to the lost and the broken, is made possible in the novel only when melodrama is staged by borrowing folk theatre idioms of heightened emotional language mythic morality and judgement...". Perhaps this method is the most faithful possible and least compromising of the integrity of both tale and reader.

\section{VII.2. Intertextuality}

The significance of text extends beyond code switching and ear candy. There are clear similarities between the way the book is told and both Bombay itself and the drug state itself. The book is highly intertextual, containing references to invented texts and real-world ones, stories within stories from a broad mix of genres (magazine articles, poems, books, song lyrics, films), and repetitions of key phrases and narratives. Among this assortment of texts, layers of reality mingle and swirl so that it is not always evident what is dream, what is nod; what is fact, what is fiction; what is past, present, future, or prophecy.

The intertextual elements of the narrative are so ubiquitous it feels we are reading or hearing a story within our story just as much as we're reading "the" story itself. In the first thirty or so pages alone, we have extracts from Time magazine ("What a big name for a small book," Dimple says), Free Press Journal, the Daily Mail, and several other papers talking about Newton Pinter Xavier, "a postmodern subversive who rejected the label 'postmodern'(25)" (could this be true of Thayil as well?); the enigmatic S. T. Pande, whose texts appear several times throughout the book; and a few poems by Xavier himself. One of these tells of a boy in a dystopian future that becomes separated from his family and homeland. 
It is through Mr. Lee, himself an exile, who "lost a war and a homeland at one stroke," that we receive perhaps the most significant text within text. Lee's father, we learn, wrote a book in 1957 that broke from his previous popular literature and whose content was incendiary enough to the Maoist government that the author was thrown in a labour camp, branded a revisionist, a forced to carry a sign reading, "I am a monster." Lee finds the book, Prophecy (another fitting title), after his father's death. As the contents are unveiled, a stir of recognition sparks, and grows the more we hear. Prophecy is "presented like a biography but there were things in it that no biographer could know, for instance the things that men and women were thinking at important moments in their lives" and "at the centre of it all was a character who was neither man nor woman."

Mr. Lee's story is the most consistently chronological narrative in Narcopolis-it tells his entire life start to finish, in one (fairly) continuous stream. Yet it comes in the middle of the book, is buried between layers of other characters' stories (and contains a few Russian tea doll texts of its own), is related to us second hand (or third depending how you spin it), and is one of the only major stories that takes place outside of Bombay (other stories are hinted at, like the narrator's time in New York City, for example, and Rumi's story of chauffeuring the rich in LA). So why China? Simply put: the opium connection. Thayil has said that living in India and China gave him knowledge of the two historic "poles" of the opium trade. And this is where Narcopolis is anchored. After all, it is Mr. Lee's story, but it is also the story of the pipe, our narrator, who originally belonged to the senior Mr. Lee - and was his constant companion during the writing of Prophecy. It seems Dom is not the only one writing down a book based on what the pipe has told him.

\section{VII.3. Multi-layering}

The jumble of genres and narratives in the novel is to certain extent an essential ingredient in a postmodern narrative. Scattered throughout narrative are references to other texts and other stories, which make the novel multi-layered. Books appear within dreams. Mr. Lee is visited by visions of his father's novel when he grows older and closer to death. Dimple has a parallel vision too. Before he drops her at rehab, Dom takes Dimple to Chowpatty Beach and has a "moment of clairsentience" where he reports that Dimple was looking for the ghost ship on the horizon, reflecting the ghost ship Mr. Lee looked for recalling what his father had written about Zheng He. Dimple later writes a story, that Dom finds, in which a boy has similar visions.

What we have in the novel are many different stories, many different storytellers, and many modes of seeing these same stories. We are also made to realise layers of perspectives: is the story we read, a true story, a fable, a dream, a drug-induced vision, a memory? Near the beginning of Book One, the nod takes Dom and he dreams he is visited by the spirit of deceased Dimple. This dream's significance becomes clearer as the book unfolds. We begin to understand that these dream visitations may actually be from spirits, traversing time and space, to visit people who know them. Dimple tells Dom that her spirit is always there, just beyond a veil, behind a mirror's reflection, or under the surface of water. Spirits hover nearby, she says, just waiting for someone to listen.

Dreams almost merge reality and there is "only a veil... a transparent veil as flimsy as the one that separates you from your dreams" (20) It is not important if dreams touch reality and facts for "You've got to face facts and the fact is life is a joke, a fucking bad joke, or, no, a bad fucking joke" (22) Facts are like the clothes we wear. They are costumes and disguises. "The image has nothing to do with the truth. And what is truth? Whatever you want it to be. Men are women and women are men. Everybody is everything" (57). Our sense of reality has this one feature. We are dogged by a constant thought, "Anything can happen to anyone at any time" (117)

Dreams too are layered, and often contain important messages in the form of secrets or revelations of the future. "With the dreams came memories, or perhaps they weren't memories at all but fantasies she imagined were memories". (239) Dreams of a character do not just remain within the head of the dreamer. Dimple's dream of Mr. Lee leaks into Rashid while they are having sex, and Rashid sees a dream vision of his own future which Dom later witnesses come to pass. These different dimensions of reality blend with one another. For instance, Dimple says of her memories of her mother that come to her when she is detoxing (and which mix with Mr. Lee's memories of his mother): "With the dreams came memories, or perhaps they weren't memories at all but fantasies she imagined were memories."

Memories contain pain like the way dreams contain lessons. Dimple's mother gave Dimple away at age seven or eight to the Tai at the brothel where Dimple is castrated, and where she spends many years of her life. Upon explaining what she can remember of her past to her new father, Mr. Lee, Dimple is told: "Forget is best." She agrees, tired of the emotional burden: "Why remember and make yourself sad?" The slippery nature of recollection is evident in Mr Lee's response. "Why remember when anyway you memory wrong, all wrong."

Stories mix and meld into each other and states of reality are interwoven together. Indeed, flux, and the mixing, shifting, changing, defying, reincorporating of norms, expectations, cultures, languages, codes, stories, reality, etc., is central to the book, which intriguingly often departs from norms yet conforms to them at the same time. 


\section{VII.4. Magical Realism}

There are some "magical" elements like the dead speaking to the living, a talking pipe, a prophetic book called Prophecy and so on, but this "magic" is confined to the land of dreams and drugs. Its magical features actually lend strength. We are not able to dismiss anything as unreal, because it is real to the characters and perhaps even real within the book's reality as well. Possibly, a dream, an opium nod, a heroin vision, all these could also be a glimpse behind that veil separating the reader from the realm of the magical. Surely it is not a coincidence that so many of the dream apparitions directly speak of this very thing. That the magical stuff happens in the realm of dreams or the realm of the intoxicated means we have no way to dismiss it. Of course, it becomes easy to forget that the pipe's all-knowing narration comes through Dom-who has himself spoken of the impossibility of reliability. Is the pipe really speaking to him, or does he just think so? Is Prophecy really prophetic, or is the whole thing, indeed the entire book, a story he has made up? The sense is that it is genuine, as genuine as it can be anyway, but the very fact that we can't be sure makes those magical moments all the more powerful.

\section{VII.5. Subjective Secret History}

"Bombay," the book begins, "which obliterated its own history by changing its name and surgically altering its face, is the hero or 'heroin' of this story." Narcopolis is not a typical Bombay book. It did not feature the great figures of Independence or Colonial history. It is a peculiar subjective secret history told with lot of intimacy and familiarity about the world of opium dens familiar to Thayil. He had witnessed the garad heroin destroy that culture and many people's live. The history we're told in Narcopolis is easily Thayil's as much as it is the narrator, Dom Ullis's but extends far both of them. Narcopolis is about a specific India in a specific time period. We hear references to historically significant events throughout: the pathaar maar killings, when a "stone killer" preyed on Bombay are most destitute, bashing their heads in with a rock while they slept. These killings remained unsolved in the objective history of investigation but in Narcopolis do offer a potential answer to the mystery: a stone killer perhaps saw himself as a force of benevolent violence, the only solution to a broken world. And the destructive chaos of the Bombay riots in the early 90s accompanies the characters' own descent into ruin. But the book is also a timeless and universal story. As a chiromancer claims to predict the course of a human life from a line on the palm, so Narcopolis dares to tell the past 30 years of then-Bombay's history from the vantage point of a single street. That street is Shuklaji Street - since the days of the Raj the heart of the city's red-light district but by the end of the novel undergoing gentrification.

\section{VII.6. Autobiographical elements}

The novel draws on his own experiences as a drug addict, and what he calls "the lost 20 years of my life"( Potter) it took him five years to write the novel, and he called it "the opposite of catharsis. Catharsis gets stuff out of you. But this put bad feelings into me." (Jaiman) Thayil undoubtedly writes from close experience about that sordid world of pimps and prostitutes, drug addiction and sexual deviance, grotesque crime and heinous punishment. It fascinates as much as it shocks - even as one might recoil in horror, knowing he would probably never set foot in Mumbai's innards, yet one quite desire to know more about them.

When he was asked How he had gone about his research on opium-induced Bombay in the 1970s and how much of 'him' is spaced within the book, Thayil said, "All information, detailing, figures, characters, composition of chemicals were the by products of what I would like to call 'embedded research'. The novel grew out of that period of embedded journalism, of my own days into addiction and intoxication." (Mitra)

\section{Themes}

At one point in the novel, Rashid surveys his establishment and reflects: "The room made people talk in whispers, as if they were in a place of worship, which, the way he saw it, they were. Already now there were times he could feel it slipping away, the conversations that a man would begin and lose interest in, all the rituals that he revered and obeyed, all of it disappearing." In this sense Narcopolis exceeds the limits of a novel about drugs; it is a lament for everything good that time devours. Thayil's luminous debut novel completely subverts and challenges the literary traditions for which the Indian novel is celebrated. This is a book about drugs, sex, death, perversion, addiction, love, and god, and has more in common in its subject matter with the work of William S. Burroughs or Baudelaire than with the subcontinent's familiar literary lights. Above all, it is a fantastical portrait of a beautiful and damned generation in a nation about to sell its soul. Written in Thayil's poetic and affecting prose, Narcopolis charts the evolution of a great and broken metropolis.

\section{VIII.1. Enduring Relationships}

Thayil doesn't give the reader a shock-and-awe kind of story or an account of an addiction per se. In fact, ruthlessness, filth and depravity — the guts of Mumbai's underworld, and what makes it turn —along with opium-dependent existence turn out to simply be smokescreens for a story about genuine love and deep 
friendship and how they exist where you had least expected them. Early in Narcopolis, when Dom first arrives in Mumbai, a fellow opium smoker - an educated middle-class man-mockingly tells him all he has in common with "these people is smoke." Indeed, the characters in this story find themselves separated by economics, education, religion, politics, and circumstance. Opium links them but more than opium binds them. Enduring relationships prove that everyone, everywhere, high or low, is worthy of friendship and love.

Though the book is filled with violence and despair, and though the author avoids sentimentality, the book's closing is, if not entirely happy, mostly warm. It becomes clear that what these characters have been trying to obliterate, with drugs, violence, sex, religion, etc., is not the self exactly. It is not even the cold infinity of death or the strangling struggle of life - it is loneliness, the barrier between us and our loved ones, between us and the universe. Dimple, who we as readers care about most, is on to it early, when she first tries opium and finally feels beloved, "to be beloved is to be not alone." She returns to it at the end of her life: "I knew what a lucky life I was given and I understood everything ... most of all, how wrong it was to withhold affection from those who need it most, which is to say, everyone."

"I am beloved" Dimple tells Rashid, "And you, dear friend, you're beloved too." Love transcends self, time, place, life, death. In the end, despite all the book's departures from form, its unsettling violence, its drugaddled failures, despite the fact that it refuses to hit you over the head with this message (as the 'pathaar maar' might his victims, thinking he is doing them a favour), what Dom, and we, eventually see is that love conquers all. Love is hidden away in most of the book, but in the end, love is what matters, love is what allows for communication, for the dead to reach out to us, for us to move beyond that veil and no longer be alone.

\section{VIII.2. Fated Choices in Life}

Narcopolis also tells a story about choices - those who have them and those who don't. It takes place in India in the 1970s, when Mumbai was still called Bombay, and political and social turbulence reigned supreme. Thayil's story, though, could have happened and still can in any metropolis where poverty, illiteracy and deepset economic inequality dictate people's lives, where many seem pre-destined for "the usual ending," as he writes, due to a "fatherless childhood, an adolescence of petty crime, garad (smack) or alcohol... more crimes and illness", it can still be read as a story on the choices of life.

Witness the eunuch, Dimple, main character of Narcopolis. Abject poverty and other forces beyond her control drive Dimple's mother into selling her eight-year-old child. That exchange leads to the crudest form of castration - its pain will torture Dimple in later life and leave her with no option but to seek the relief of opium. Dimple naturally wonders why people with choices in life she did not have grovel on the floor in front of her, desperate for fixes. The question Dimple asks is why do people who seemingly have it all-education, jobs, families, and prospects for the future-become addicts? That impossible question never gets an answer, although it feels at times as if Thayil pushes readers to pass judgment on those for whom drugs become a deliberate choice. Why, for example, does an educated young man like Dom Ulisis (most likely a character based on Thayil himself) choose to while away the best years of his life in an opium den on Mumbai's Shuklaji Street after a bust by cops in New York and deportation to India?

Readers might empathize with Salim, a petty black market scotch and cocaine peddler whose powerful boss regularly sodomizes him. But then question the choices the renowned artist Newton Xavier, a drunk and a junkie with fame and fortune and scores of admirers around the world makes. He gets wasted on opium simply because he has never tried it before. He has sex with Dimple the eunuch just for the heck of it. Then his wealth and standing allow him simply to walk away from it all. He cleans up and makes an appearance in front of adoring, unsuspecting fans ... to "give them what they want." Thayil leaves the reader with a realization that the line between those born with choices and those not so lucky is very thin. The side of the divide one is born on is purely random.

\section{VIII.3. Empathy}

Thayil had said in one of his earlier interviews that by writing this book he wanted to "honour the addicted, the marginalised and people perceived to be the lowest of the low". The book was born out of empathy. The book in a way challenges the negative thoughts that we harbour for addicts, it urges us to have an open mind toward them. (Mitra) The literature of drugs can be both wearisome and curiously smug: low-life glamour exulted with florid prose and cod-spiritual awakenings. And while ghosts, visions and trash-can decadence occasionally cloud the atmosphere, Thayil's sympathy, range and clear-eyed, yet fluid style finds something other in the addict's cycle of relief and relapse. Ultimately this is a novel of escape. Disparate characters meet at the den, leaving behind the complications the world outside presents. And while this is hardly a groundbreaking interpretation of narcotic abuse, Thayil subtly inhabits lives destined to forever end back to the pipe: Dimple, a transsexual prostitute; Mr Lee, a Chinese soldier, son of a dissident writer and a communist zealot mother; Rashid, a drug dealer still in thrall to the old ways, wilfully ignorant to the changing society around him. Their sadness and their shattered lives are depicted with empathy and a sharp eye for the dark 
comedy that resides there. After Dimple tries the new garad heroin, she has a hallucination in which she is visited by dead Lee. "I'm here because my spirit has not been able to travel to its rightful place, he said. I've left my body or my body has left me, which is the first death. The second death occurs when those who love us and are loved by us also die, or forget, and our names are no longer spoken"(183)

\section{Conclusion}

In ambition, Narcopolis is reminiscent of Roberto Bolano; but it is Denis Johnson's Jesus' Son - the best junkie book of the last quarter century - that is its closer kin. It may seem that Dimple apart, none of the characters is in the least bit nice: they are to a man greedy, needy, egotistical and prone to bursts of irrational violence. Yet Thayil has shown he is a poet, and it shows in the prose, which contains countless moments of great beauty. The book, indeed, is studded with scenes of shocking physical violence. Bombay in the 1970s is a cauldron which frequently boils over. At the end of the book the readers are to admit his debut is an unsettling portrait of a seething city, a beautifully-written meditation on addiction, sex, friendship, dreams, and murder. It's a simultaneously brutal and beautiful work, dreamlike without ever being sentimental or vague or softhearted. Narcopolis is a truly impressive achievement.

\section{References}

[1]. Alison, Flood. "Man Asian literary prize shortlist stages Booker re-match". The Guardian. January 9, 2013

[2]. $\quad$ "BBC News - Man Booker 2012: Shortlist at a glance". BBC Online. 11 October 2012.

[3]. Farooqui, Amar.Opium City: The Making of Early Victorian Bombay. New Delhi: Three Essays Collective, 2006. Print.

[4]. Ghosh, Amitav. Sea of Poppies. New York: Farrar, Straus and Giroux, (2008).Print

[5]. ... River of Smoke. New York: Farrar, Straus and Giroux, (2011).Print.

[6]. Huggan, Graham. The Postcolonial Exotic: Marketing the Margins. New York: Routledge, 2001. Print.

[7]. Jaiman, Anuja (11 October 2012). "Book Talk: Booker nominee Thayil offers bleak Bombay portrait". Reuters. 15 October 2012.

[8]. Khair, Tabish. Babu Fictions: Alienation in Contemporary Indian English Novels. Oxford University Press, 2001.Print.

[9]. Mitra, Ipshita. "Narcopolis was born out of empathy: Jeet Thayil" Dec 19, 2012 timesofindia.indiatimes.com

[10]. Mukherjee, Upamanyu Pablo. Postcolonial Environments, Nature, Culture and Contemporary Indian Novels in English. Basingstroke: Palgrive MacMillan, 2010. Print.

[11]. Potter, Emma Lee (12 October 2012). "Booker looks too tight to call". Daily Express. Retrieved 15 October 2012.

[12]. Samantara, Pratiek. "Exploring India's Dark Heart: On Jeet Thayil and Narcopolis" http://theculturetrip.com/asia/india/articles/

[13]. Singh, Anita (12 September 2012). /booker-prize/9537028/Booker-Prize-shortlist-turns-its-back-on-readability.html "Booker Prize shortlist turns its back on 'readability'". The Daily Telegraph. 15 October 2012.

[14]. The Hindu. "The Hindu Literary Prize goes to Jerry Pinto". February 18, 2013.

[15]. Thayil, Jeet. Narcopolis. London: Faber and Faber, 2012. Print

[16]. ... "The Man Booker 2012 shortlist: the authors on their novels". The Guardian. 15 October 2012.

[17]. Welsh, Irvine. Trainspotting London: Martin Secker\&Warburg, 1993. 